\title{
The Influence of Marital Adjustment and Family Function on Family Strength in Early Marriage
}

\author{
Dita Septia Ningsih* \\ Department of Family and Consumer \\ Sciences, \\ Faculty of Human Ecology, \\ Bogor Agricultural University \\ *Corresponding author: ditaseptia4@gmail.com \\ Tin Herawati \\ Department of Family and Consumer \\ Sciences, \\ Faculty of Human Ecology, \\ Bogor Agricultural University
}

\begin{abstract}
The aim of this study is to examine the influence of marital adjustment and family function toward family strength in early marriage. The location of this research are Cibeber II village and Karehkel village, Leuwiliang sub-district, Bogor district, West Java. Samples of this study are 60 mothers from an early marriage family (under 20 years old) whose children are under five years old, and willingly to take part in this study. Samples were chosen purposely. There was correlation of age of husbands and age of husbands when married that showed negative significant correlation with family strength. Income, marital adjustment, and family functions wae positively significant correlate with family strength. The factors that affect family strength were income, marital adjustment, and family function
\end{abstract}

Keywords : family function, family strength, marital adjustment

\begin{abstract}
Abstrak
Penelitian ini bertujuan untuk mengetahui pengaruh penyesuaian perkawinan dan fungsi keluarga terhadap ketahanan keluarga menikah dini. Lokasi penelitian di Desa Cibeber II dan Desa Karehkel, Kecamatan Leuwiliang, Kabupaten Bogor, Jawa Barat. Responden pada penelitian ini adalah ibu yang menikah usia dini (dibawah 20 tahun) memiliki anak balita serta bersedia untuk dijadikan responden sebanyak 60 orang. Responden dipilih secara purposive. Terdapat hubungan yang menunjukkan bahwa usia suami dan usia menikah suami berhubungan negatif signifikan terhadap ketahanan keluarga. Pendapatan, penyesuaian perkawinan, dan fungsi keluarga berhubungan positif signifikan terhadap ketahanan keluarga. Faktor yang berpengaruh terhadap ketahanan keluarga adalah pendapatan per kapita, penyesuaian perkawinan, dan fungsi keluarga.
\end{abstract}

Keywords : fungsi keluarga, ketahanan keluarga, penyesuaian perkawinan 


\section{INTRODUCTION}

According to the Bureau of National Population and Family Planning/BNPFP (2012) early marriage is a marriage conducted under the age of 20 years. Indonesia is ranked 37th among countries with the highest number of early marriages in the world (World Fertility Policies, United Nations, 2011). According to research data from the Center for Gender and Sexuality Studies University of Indonesia (2015), the number of early marriages in Indonesia ranked second in Southeast Asia after Cambodia. Young women aged 15-19 years who married bigger the impact of young men aged 15-19 years (Basic health research 2010). According to the InterCensus Population Survey Analysis (2012) of BNPFP published below it is lower than in rural areas. Marriage at a young age is prone to conflict and divorce. Age being married will affect a person's maturity in running a household.

According to Yezingew et al. (2014) the age of marriage is an important factor influencing the adjustment of marriage. Bowman and Spanier (1978) and Burgess et al (1971) say that very young married people have a lower marital adjustment than married in mature age. According to Khairi (2016) the couple who meet the aspects of marital adjustment rarely quarrel and rarely talk about divorce. Lack of marital adjustment will have an impact on family resilience and welfare in the household. According to Anjani and Suryanto (2006) several supporting factors in the adjustment of marriage include maintaining good relationships, mutually instilling a sense of love, and mutual respect. The family's ability to make marital adjustments will be followed by the family's ability to do its functions. According Sunarti (2001) and Soeradi (2013) if the family do its functions will optimally affect the family resilience. This will make low-level conflicts within households and families able to deal with problems well. According to Utami (2015) adjustment means the family is able to harmonize with the demands of the environment, so that the pressing situation will be successfully overcome.

Therefore, this study aims to: (1) Identify family characteristics, marital adjustment, family function, and resilience of early married families, (2) analyze the relationship between family characteristics, marital adjustment, and family functions with early married family resilience, and (3) Analyzing the influence of family characteristics, family adjustment, and family functions on the resilience of early married families.

\section{RESEARCH METHOD}

The research was conducted by using cross sectional study design, that is research which impelemented by researching at one time using interview method using questioner. The selection of research sites was done purposely, in Cibeber Village II and Karehkel Village, Leuwiliang District, Bogor Regency. Leuwiliang district has a number of couples who married quite high as many as 1195 couples. Cibeber Village II and Desa Karehkel become rural representatives who have a fairly high underage marriage rate among the villages in Leuwiliang District (Ministry of Religious Affairs 2016). The study period from January 2017 to June 2017 included preparation, data collection, data processing, data analysis and report writing.

The research data are primary data. The data includes: (1) Family sample characteristics (husband's age, wife's age, marital age of husband, marital age of 
wife, marriage length, number of family members, length of husband's education, wife's length of education, husband's occupation, wife's occupation, and per capita income), (2) The marriage adjustment in this study used questionnaires referenced and modified from Spanier (1976) Dyadic Adjustment CBSle (DAS) with Cronbach alpha 0.838 , (3) The family function in this study used questionnaires referenced from The National Population and Family Planning's family function (2012) and Sopiah (2014) with Cronbach alpha 0.802, (4) Family resilience in this study used questionnaires referenced and modified from Sunarti (2001) with Cronbach alpha 0.708 .

The information collected is processed through the process of editing, coding, entering, cleaning, and analyzing. Data analysis using Microsoft Excel for Windows and SPSS 16.00 for Windows programs. Data were analyzed descriptively (mean, standard deviation, minimum value and maximum value) and inferences (multiple linear correlation and regression).

\section{Family Characteristics}

\section{RESULT}

The average age of the husband is 28.0 years and the wife is 20.5 years old. The average age of married husband is 24.8 years and wife is 17.3 years old. The average of husband education is 8.4 years and the wife's average education is 7.5 years. Long married husband and wife ranged from 1 to 5 years of age marriage. The average number of family members is included in the small family category ( 3 people). Average per capita income per month is above the Bogor poverty line of 619513 (Central Bureau of Statistic 2016). Most of the husband's work is as a laborer and his wife is all working as a housewife.

\section{Marital adjustment}

Based on the results of the research, in Table 1 shows that more than threequarters of respondents (76.7\%) adjusted their marriage in the medium category. This can be seen from the aspect of agreement, unity, satisfaction, and showing affection (Spainer 1976).

Table 1 Distribution of the family based on marital adjustment

\begin{tabular}{|c|c|c|c|c|c|c|c|c|}
\hline \multirow{3}{*}{$\begin{array}{c}\text { Dimension of } \\
\text { Marital Adjustment }\end{array}$} & \multicolumn{6}{|c|}{ Category } & \multirow{3}{*}{$\begin{array}{l}\text { Minimum- } \\
\text { Maximum }\end{array}$} & \multirow{3}{*}{$\begin{array}{c}\text { Average } \pm \\
\text { Deviation } \\
\text { Standard }\end{array}$} \\
\hline & \multicolumn{2}{|c|}{$\begin{array}{l}\text { Low } \\
(<60)\end{array}$} & \multicolumn{2}{|c|}{$\begin{array}{c}\text { Medium } \\
(60-80)\end{array}$} & \multicolumn{2}{|c|}{$\begin{array}{l}\text { High } \\
(>80)\end{array}$} & & \\
\hline & $\mathrm{n}$ & $\%$ & $\mathrm{~N}$ & $\%$ & $\mathrm{~N}$ & $\%$ & & \\
\hline Agreement & 2 & 3.3 & 36 & 60.0 & 22 & 36.7 & $0-100$ & $75.8 \pm 15.0$ \\
\hline Integrity & 1 & 1.7 & 1.7 & 3.3 & 58 & 96.7 & $0-100$ & $87.7 \pm 12.6$ \\
\hline Satisfaction & 8 & 13.3 & 21 & 35.0 & 31 & 51.7 & $28-85$ & $74.6 \pm 11.4$ \\
\hline Showing Affection & 47 & 78.3 & 13 & 21.7 & 0 & 0 & $12-79$ & $46.2 \pm 15.5$ \\
\hline Total & 4 & 6.7 & 46 & 76.7 & 10 & 16.7 & $9-89$ & $70.2 \pm 11.2$ \\
\hline
\end{tabular}

Aspects of the deal fall into the medium category. This is evident from the statement of respondents often discussing work issues, often having an agreement in the division of household duties, often discussing on major decisions. However, there is still the lowest achievement because the respondent has never done financial 
handling together and never do recreation when the holiday. The aspect of alignment belongs to the high category. This is evident from respondents' statements that often exchanged ideas, often supported each other, often discussed the problem calmly. The aspect of satisfaction belongs to the high category. This is evident from the statement of respondents who never feel nervous when with a partner, never regretted marrying a spouse, never left home during a fight, never talked about divorce. Aspects of showing affection fall into the low category. This can be seen from the statement of respondents who rarely have sex, never celebrate the birthday with a partner, and never do a romantic thing.

\section{Family Function}

Based on the results of the study, (Table 2) more than three-quarters of wives $(78.3 \%)$ family functions are in the medium category. This can be seen from the function of religion, sociocultural function, the function of love, the function of protection, the function of reproduction, the function of educational socialization, the economic function, and the function of environmental development (NPFP 2012).

Table 2 Distribution of the family based on family function

\begin{tabular}{|c|c|c|c|c|c|c|c|c|}
\hline \multirow{3}{*}{$\begin{array}{l}\text { Dimension of Family } \\
\text { Function }\end{array}$} & \multicolumn{6}{|c|}{ Category } & \multirow{3}{*}{$\begin{array}{l}\text { Minimum- } \\
\text { Maximum }\end{array}$} & \multirow{3}{*}{$\begin{array}{c}\text { Average } \pm \\
\text { Deviation } \\
\text { Standard }\end{array}$} \\
\hline & \multicolumn{2}{|c|}{$\begin{array}{l}\text { Low } \\
(<60)\end{array}$} & \multicolumn{2}{|c|}{$\begin{array}{r}\text { Medium } \\
(60-80)\end{array}$} & \multicolumn{2}{|c|}{$\begin{array}{l}\text { High } \\
(>80)\end{array}$} & & \\
\hline & $\mathrm{N}$ & $\%$ & $\mathrm{n}$ & $\%$ & $\mathrm{~N}$ & $\%$ & & \\
\hline Religious function & 11 & 18.3 & 42 & 70.0 & 7 & 11.7 & $43-90$ & $68.5 \pm 10.7$ \\
\hline Social culture function & 1 & 1.7 & 21 & 35.0 & 38 & 63.3 & $50-100$ & $84.2 \pm 9.0$ \\
\hline Affectional function & 1 & 1.7 & 15 & 25.0 & 44 & 73.3 & $0-100$ & $85.8 \pm 14.8$ \\
\hline Protectional function & 2 & 3.3 & 34 & 56.7 & 24 & 40.0 & $30-100$ & $78.8 \pm 11.3$ \\
\hline Reproductive function & 25 & 41.7 & 25 & 41.7 & 10 & 16.7 & $36-90$ & $63.9 \pm 13.8$ \\
\hline $\begin{array}{l}\text { Socialization of } \\
\text { education function }\end{array}$ & 0 & 0 & 15 & 25.0 & 45 & 75.0 & $63-100$ & $86.3 \pm 8.6$ \\
\hline Economic function & 24 & 40.0 & 31 & 51.7 & 5 & 8.3 & $23-90$ & $62.4 \pm 15.3$ \\
\hline $\begin{array}{l}\text { Environmental } \\
\text { coaching function }\end{array}$ & 23 & 38.3 & 37 & 61.7 & 0 & 0 & $43-80$ & $60.4 \pm 8.3$ \\
\hline Total & 2 & 3.3 & 47 & 78.3 & 11 & 18.3 & $53-87$ & $73.6 \pm 7.0$ \\
\hline
\end{tabular}

Religious functions fall into the medium category. This can be seen from the statement of respondents who always give religious facilities, always tolerate with neighbors, and always reminded when neglecting to run religious orders. But there are still respondents who never follow religious activity, never teach religious activities to children. Sociocultural functions fall into the high category. This is evident from the statement of respondents who always follow the customs of the adhered to, always appreciate the customs that are held, always give an example of responsibility. The function of love belongs to the high category. This is evident from the statement of respondents who always receive shortcomings and excess couples, always calling the couple with a good call, always expressing hope for family harmony. The protection function belongs to the moderate category. This is evident from the statement of respondents who always care for family members 
who are sick, always discussing the inconvenience of the household. But there are still respondents who stated never use health insurance, never provide drugs at home. Reproductive functions fall into the low category. This can be seen from the statement of respondents who have never planned the period of having children, never checked health, never get used to exercise. The function of educational socialization is included in the high category. This can be seen from the statement of respondents who always call a certain title to the older or younger, always say thank you, and always get used to taking the gift with the right hand. Economic functions are included in the medium category. This can be seen from the statement of respondents who always prioritize the main needs, always thinking about crediting. But there are still respondents who have never made a record of income and financial expenses, never saving, never set aside income for emergency purposes. The function of environmental coaching is included in the medium category. This is evident from the statement of respondents who always throw garbage in place, always cleaning the house, always keep the goods in place. But there are still respondents who never cut the use of plastic bags, never recycle used goods.

\section{Family Resilience}

Based on the results of the study in Table 3 shows that more than threequarters of wives $(75.0 \%)$ feel that their family resilience is in the medium category. This can be seen from aspects of physical resilience, social resilience, and psychological endurance (Sunarti 2001).

Physical resistance is included in the low category. This is reflected in the statement of the respondent does not own his own home, and does not own his own land of, does not have a guarantee of healthy. On social resilience is in the high category obtained from the statement respondents accept the current state, have goals and goals achieved, feel comfortable residing in the neighborhood. In psychological endurance is in the category of being obtained from the statement respondents mutual feelings, help each other, have a good relationship with in-laws. But there is still anxiety in the future, not satisfied with the income earned, and not yet a good partner.

Table 3 Distibution of family based on family resilience

\begin{tabular}{|c|c|c|c|c|c|c|c|c|}
\hline \multirow{3}{*}{$\begin{array}{l}\text { Dimension } \\
\text { of family } \\
\text { resilience }\end{array}$} & \multicolumn{6}{|c|}{ Category } & \multirow{3}{*}{$\begin{array}{l}\text { Minimum- } \\
\text { Maximum }\end{array}$} & \multirow{3}{*}{$\begin{array}{c}\text { Average } \pm \\
\text { Deviation } \\
\text { Standard }\end{array}$} \\
\hline & \multicolumn{2}{|c|}{$\begin{array}{l}\text { Low } \\
(<60)\end{array}$} & \multicolumn{2}{|c|}{$\begin{array}{l}\text { Medium } \\
(60-80)\end{array}$} & \multicolumn{2}{|c|}{$\begin{array}{l}\text { High } \\
(>80)\end{array}$} & & \\
\hline & $\mathrm{n}$ & $\%$ & $\mathrm{n}$ & $\%$ & $\mathrm{~N}$ & $\%$ & & \\
\hline Physic & 27 & 45.0 & 26 & 43.3 & 7 & 11.7 & $18-90$ & $58.8 \pm 15.6$ \\
\hline Social & 1 & 1.7 & 1 & 1.7 & 58 & 96.7 & $45-100$ & $93.2 \pm 9.2$ \\
\hline Psychologic & 9 & 15.0 & 40 & 66.7 & 11 & 18.3 & $25-100$ & $67.8 \pm 14.7$ \\
\hline Total & 4 & 6.7 & 45 & 75.0 & 11 & 18.3 & $40-96$ & $74.0 \pm 9.9$ \\
\hline
\end{tabular}

\section{Relationship of Family Characteristics with Marriage Adjustment, Family Function and Family Resilience}

Table 4 shows the correlation between family characteristics, marital adjustment, family function and family resilience. The results showed that the age of husband and married age of husband significantly negative correlation with 
marital adjustment. This shows that the higher the difference between husband's age and married age of husband the lower the adjustment of marriage. Revenue is positively related to family resilience. In accordance with previous research Trijayanti (2015) stating that income is positively related to family resilience. The higher the income the family resilience will increase. Adjustment of marriage and family functions is positively significant with family resilience. The higher the adjustment of marriage and family functions will increase the resilience of early married families.

Table 4 Relationship of family characteristics with marital adjustment, family function and family resilience

\begin{tabular}{lccc}
\hline Variable & Marital Adjustment & Family Function & $\begin{array}{c}\text { Family } \\
\text { Resilience }\end{array}$ \\
\hline Age of wife & -0.194 & -0.093 & 0.008 \\
Marital Age of wife & -0.131 & -0.047 & 0.010 \\
Education length of wife & 0.247 & 0.185 & 0.226 \\
Age of wife & $-0.368^{* *}$ & -0.131 & -0.249 \\
Marital Age of wife & $-0.349^{* *}$ & -0.155 & -0.249 \\
Education length of wife & 0.234 & 0.243 & 0.246 \\
Lenght of marriage & -0.091 & -0.040 & 0.037 \\
Family size & 0.045 & 0.017 & 0.015 \\
Income & 0.082 & 0.100 & $0.273^{*}$ \\
Marital Adjustment & 1.000 & $0.751^{* *}$ & $0.676^{* *}$ \\
Family Function & $0.751^{* *}$ & 1.000 & $0.620^{* *}$ \\
Family Resilience & $0.676^{* *}$ & $0.620^{* *}$ & 1.000 \\
\hline Description: $*$ Significant correlation at $\mathrm{p}<0.05, * *=$ Significant correlation at $\mathrm{p}<0.01$
\end{tabular}

\section{Influence of Family Characteristics, Marital Adjustment, Family Function and Family Resilience}

The result of linear regression analysis of variable model to family resilience shows Adjusted R Square number is 0.465 which explains that 46.5 percent of variable model under study influences family resilience and the remaining 53.5 percent is influenced by other variables outside of the research. The result of the research indicated that opinion $(\beta=0.202 ; \mathrm{p}=0.060)$, marriage adjustment $(\beta=$ $0.440 ; p=0.011)$, and family function $(\beta=0.259 ; \mathrm{p}=0.093)$ had positive and significant effect on family resilience.

Regression test results show that every increase of one dollar income will increase the family resilience by. $328 \times{ }^{10-6}$ points. Furthermore, every increase of one point of marital adjustment will increase the family resilience by 0.391 points, as well as every increase in one point of family function, it will raise the family resilience by 0369 points. This suggests that the better marriage adjustment and ideal family function can increase family resilience. Similarly with income, the higher the income will increase family resilience. 
Table 5 The influence of family characteristics, marital adjustment, and family functions on family resilience

\begin{tabular}{|c|c|c|c|c|}
\hline \multirow[b]{2}{*}{ Variable } & \multicolumn{4}{|c|}{ Koefisien } \\
\hline & $\begin{array}{l}\text { Unstandardized } \\
\text { Coeeficient (B) }\end{array}$ & Error Std & $\begin{array}{c}\text { Standardized } \\
\text { Coeeficient }(\beta)\end{array}$ & Significant \\
\hline Constant & 6.211 & 23.951 & & 0.769 \\
\hline Age of wife (year) & 0.714 & 0.816 & 0.102 & 0.386 \\
\hline $\begin{array}{l}\text { Education length of wife } \\
\text { (year) }\end{array}$ & -0.049 & 0.592 & -0.009 & 0.934 \\
\hline Age of husband (year) & -0.514 & 1.070 & -0.192 & 0.633 \\
\hline $\begin{array}{l}\text { Marital Age of Husband } \\
\text { (year) }\end{array}$ & 0.266 & 1.058 & 0.100 & 0.802 \\
\hline $\begin{array}{l}\text { Education length of } \\
\text { husband (year) }\end{array}$ & 0.193 & 0.426 & 0.048 & 0.652 \\
\hline Family size (person) & -0.018 & 4.106 & 0.000 & 0.996 \\
\hline Per capita income (IDR) & $8.328 \mathrm{E}-6$ & 0.000 & 0.202 & $0.060 *$ \\
\hline Marital Adjustment (score) & 0.391 & 0.148 & 0.440 & $0.011 * *$ \\
\hline Family function (score) & 0.369 & 0.216 & 0.259 & $0.093 *$ \\
\hline F test & \multirow{2}{*}{\multicolumn{4}{|c|}{$\begin{array}{c}6.696 \\
0.000 * *\end{array}$}} \\
\hline Sig & & & & \\
\hline R Square & \multicolumn{4}{|c|}{0.547} \\
\hline Adjusted $R$ Square & \multicolumn{4}{|c|}{0.465} \\
\hline
\end{tabular}

Description: $*=$ Significant correlation at $\mathrm{p}<0.1, * *=$ Significant correlation at $\mathrm{p}<0.05$

\section{DISCUSSION}

The results showed that the average age of husband and wife age was in early adulthood (Hurlock 1980). The average education taken by husband and wife does not complete junior high school. Most husbands work as laborers and wives as housewives. According to Hasmi et al (2007) education affects one's education. The higher a person's education will get a better job. Average per capita income per month is Rp619 514, the figure is far from the Bogor poverty line of 290874 IDR (CBS 2016). According Deaton (2010) that the amount of income can lead to satisfaction in one's life. The average length of married husband and wife that is for three years. According to Sholihah (2013) long married into factors that affect family resilience.

The results show that more than three quarters of respondents make marital adjustments in the medium category. According to Hasmi et al (2007) adjustment of marriage is a happiness and satisfaction of husband and wife. with their marriages to each other. But there is still a low marital adjustment showing affection. The lack of affection shows the lack of verbal affection of husbands to wives and the treatment of husbands when different after marriage. According to Grandon et al (2004) that in a communication and agreement relationship in showing that affection is important in the family.

The results showed that family function was in the medium category. According to Endah (2015), the achievement of family function is seen from the ability to carry out his duties on the environment and members of his family. There are still relatively low family functions such as reproductive functions that do not have health checks and are planning to have children, economic functions do not 
make financial records and save, and environmental coaching functions are not able to use the surrounding environment resources properly. According to Rachmadani (2013) that the source of conflict within the family is an economic problem. According to NPFP (1992), the ideal family function is the ability to fulfill the eight aspects of family function which include religious, social, According to Sunarti et al. (2009) that the output of family resilience is determined by the function of the family so that survival can be maintained to achieve the purpose of family life

The results showed that overall family resilience was moderate. Physical endurance falls into the low category. This is because there are still family difficulties in meeting the needs of board, food, medicine, and education. According to Kusumo and Simanjuntak (2009) that low income will create dissatisfaction on physical resources because the need is not fulfilled, but the family nonphysical resources will be satisfied. In high social resilience is due to the ability of families in the division of the role of duties in the household, provide support and have goals and goals to be achieved. According to Sunarti (2001) high social resilience if the family has good nonphysical resources, good coping mechanisms to meet its social needs

In this study, the relationship test results showed that the age of husband and married age of husband significantly negative correlation with marital adjustment. This indicates that the higher the age of husband and married age of the husband the lower the adjustment of marriage. Differences in husband's age with a wife so high alleged husband difficult to make adjustments to wives who have a younger age. According to Arshad et al (2014) that mature wives have better marriage adjustments than married wives. According to Burgess and Locke (1971) marriage age makes the determinant of success in marital adjustment. According to Manyam and Junior (2014) the adjustment of marriage depends on how well the couple understands their partner with each other even though their age is different.

Revenue is positively related to family resilience. This is in line with Sholihah's research (2013) which says that increased income can increase the resilience of his family. High income makes it easy for a person to meet his needs including physical needs (Sunarti 2001). The results also show that marital adjustment is positively related to family resilience. According to Basharpoor and Sheykholeslami (2015), marriage adjustment becomes the key determinant in the family as the family functioning that is seen from the family performs the role and function of the family well to maintain the resilience of the family.

The results of the effect test show that income has a significant positive effect on family resilience. This is in line with Herawati et al (2012) study which states that family resilience increases if there is an increase in per capita income per month. Thus, if the family income is high and able to meet the needs then it will increase the resilience of his family.

Adjustment of marriage and family functions affects family resilience. According Sunarti (2001) that family resilience is related to family adaptability and family function optimization. Family functions need to be optimized with eight reference family functions according to BNPFP to achieve family resilience. According to Bade (1991), high marriage adjustment can improve family function so that family function can run well to family. 
This study has limitations that can be used as an improvement for later research, namely: (1) the study only interviewed the wife alone without involving the husband, (2) the husband of the respondent did not make the early marriage, ideally both married early.

\section{Conclusion}

\section{CONCLUSION AND SUGGESTION}

The average age of married wives at the age of 17 years and married age husband at the age of 25 years. The average level of education last taken by husband and wife is elementary school. The example family category is a small family ranging from 3 to 4 people with an average length of marriage of 3 years. All wives work as housewives and the average husband work as laborers. Income per capita per month is $\mathrm{Rp} 619$ 514. Overall marriage adjustment is included in medium category. The highest marital adjustment is obtained from the dimensions of unity and dimension of satisfaction. The lowest marriage adjustment on the dimension shows affection. Overall family functions fall into the medium category. The highest family function is achieved by the function of love and socialization function of education, while the lowest family function is achieved by the function of reproduction, economic function, and environmental coaching function. Overall, family resilience is included in the moderate category. The highest family resilience is achieved by the dimension of social resilience, while the lowest resistance is obtained in the dimensions of physical endurance.

The result of the relationship test showed that husband's age and married age were negatively related to marital adjustment. Income, adjustment of marriage and family functions are positively associated with family resilience. Factors that have a significant positive effect on family resilience are income, marital adjustment, and family function

\section{Suggestion}

Based on the research conducted, the suggestions that can be given are as follows: (1) Wives who work as housewives are given skills such as skills in utilizing the home environment and utilizing used goods, (2) Adjustment of marriage is low, especially in dimensions show affection can be improved by improving togetherness with the partner optimally, (3) Low family function such as reproduction function, economic function, and environmental coaching function can be improved with the help of health counseling, how to manage finance and good environmental management from NGOs or universities , (4) Low family resilience, ie, physical resilience can be increased by increasing family income.

\section{REFERENCES}

Anjani, C., Suryanto . (2006). The pattern of marital adjustment in the early period. Insan Journal. 8(3) : 198-210. 
Arshad M, Mohsin M.N., Mahmood, K.(2014). marital adjustment and life satisfaction among early and late marriages. Journal of Education and Practice. 5(17): 83-90.

Bade, A.D. (1991). The relationships between marital adjustment, family functioning, task management and family relationship concern in couples incorporating a second child [Dissertasion]. Michigan (ID): Western Michigan University.

Basharpoor, S., Sheykholeslami, A. (2015). The relation of marital adjustment and family functions with quality of life in women. Europe's Journal of Psychology. 11(3): 432-441.

BNPFP. (2012). Early marriage in several provinces in Indonesia: the impact of overpopulation, the root of the problem, and the role of institutions in the region.. Jakarta (ID): Bureau of National Population and Family Planning.

[CBS] Central Bureau of Statistic. (2016). Guidelines for national socioeconomic survey data collection in 2016. Central Jakarta: Central Bureau of Statistic.

Burgess, E.W., Locke, H.J. (1960). The Family from Institution to Companionship. 2nd edition. New York: American Book Company.

Endah, N.Y. (2016). The Effect of Family Function and Conflict on Family Subjective Well-being with Migrant Husband. Journal of Family Sciences. 1 (2) : $1-12$.

Grandon, J.R.R., Myers, J.E., Hattie, J.A. (2004). The relationship between marital characteristics, marital interaction processes, and marital satisfaction. Journal of Counseling and Development. 82 (1): 58-68.

Hasmi, H.A., Khurshid, M., Hassan, I. (2007). Marital Adjustment, Stress and Depression Among Working and Non-Working Married Women. Journal of Medical. 2 (1): 19-26

Herawati, T., Diah, K., Rukmayanti, I.Y. (2012). Social support and family resilience of participants and not participants of national self-help community programs. Journal of Family and Consumer Science. 5(1): 1-10.

Hurlock, E.B. (1980). Developmental psychology (an approach throughout the life span). Translation of: Developmental Psychology. Jakarta (ID): Erlangga.

Khairi, K. (2016). The influence of economic pressures and marital adjustment to the marital satisfaction of married young families. [Underthesis]. Bogor (ID): Institut Pertanian Bogor.

Kusumo, R.A.B., Simanjuntak, M. (2009). The level of low-income family satisfaction of the resources owned. Journal of Family and Consumer Science. 2: 122-136.

Manyam, S.B., Junior, V.Y. (2014). Marital Adjustment Trend in Asian Indian Families. Journal of Couple \& Relationship Therapy, 13:114-132

Gender and Sexuality Study Center of Indonesian University. (2015) Early marriage triggers problems. Women's Journal. 1(1): 1

Sholihah, F.V. (2013). Family Resource Resource Management and Family Resilience of Elderly People. [Underthesis]. Bogor (ID): Institut Pertanian Bogor.

Soeradi. (2013). Social change and family resilience: breaking local power-based policies. Information. 18(2):83-94. 
Sopiah, N.N. (2014). Self-concept, function and prosperity of Chinese and Betawi family in Sukasari Village, Tangerang Sub-district, Tangerang City [Underthesis]. Bogor (ID) : Institut Pertanian Bogor.

Spanier, G. (1976). Measuring dyadic adjustment: new CBSles for assessing the quality of married and similar dyadic. Journal of marriage and the family. 38 (1): 15-28.

Spainer, G., Bowmen. (1978). Modern Marriage. New York : Mc Graw Hill Companies.

Sunarti, E., Hernawati, N., \& Nuryani, N. (2009). The relationship between the function of adaptation, goal attainment, integration, and system maintenance with family well-being. Journal of Family and Consumer Sciences. 2 (1), 110 .

Sunarti, E. (2001). Family resilience studies and measures: Case study of the effect on the quality of pregnancy [Disertassion]. Bogor (ID) : Institut Pertanian Bogor.

Trijayanti, L. (2015). The influence of economic pressures and coping strategies on family resilience to young married families [Underthesis]. Bogor (ID): Institut Pertanian Bogor.

Utami, F.T. (2015). Adjustment of young girls who married young. Journal of Islamic Psychology. 1 (1): 11-21

Yizengaw, S.S., Kibret, B.T., Gebiresilus, A.G., Sewasew, D.T. (2014). Marital Adjustment Among Early, Age-Appropriate Arranged and Love-Matched Marriage, Motta, North West Ethiopia. Innovare Journal Of Social Sciences. 2(4): $65-73$ 